УДК 346.34

DOI https://doi.org/10.32849/2663-5313/2019.12.21

\title{
Наталія Никитченко,
}

докт. юрид. наук,

завідувач кафедри господарського права та прощесу

Університету державної фіскальної служби України

\section{Владислав Остринсвкий,}

аспірант кафедри господарського права та процесу

Університету державної фіскальної служби України

\section{ГЕНЕЗА ПОНЯТТЯ ЕРС-КОНТРАКТ ЯК ОСОБЛИВОГО ВИДУ ЗМІШАНОГО ДОГОВОРУ}

Оскільки суспільні відносини в Украӥні розвиваються стрімкими темпами, національне законодавство не встигає здійснювати їх належне правове регулювання, що примушує суб'єктів господарювання все частіше використовувати норми закордонних юрисдикцій чи проформи міжнародних профільних організачій для здійснення договірних транзакцій. $У$ статті наведено приклади того, як саме на практиці врегульовуються складні договірні відносини, чому українському законодавству необхідні зміни та яким чином зараз господарюючі суб'єкти вимушені діяти заради захисту власних інтересів під час укладення договорів з будівництва об'єктів «під ключ».

Стаття присвячена вивченню генези поняття ЕРС-контракт та його правової природи. Авторами досліджені питання виникнення типових проформ, розроблених Міжнародною Федерачією Інженерів-Консультантів. Зокрема, увага приділена так званій «Срібній книзі», яка передбачає реалізачію проєктів будівничтва «під ключ» і можливості ї застосування суб'єктами господарювання в Украйні. Дослідження містить загальний аналіз ЕРС-контракту, зроблений через призму украӥнського законодавства, в якому визначено його особливості та вказано на проблемні питання його укладення і виконання. Запропоновано авторське визначення поняття «ЕРС-контракт» з огляду на те, що ией договір є непойменованим, змішаним та має притаманні лише йому особливі риси.

Також у статті здійснено аналіз застосування окремих положень господарського та цивільного законодавства, які відображаються в ЕРС-контрактах. Це особливості погодження проєктнокошторисної документачї, укладення договору генерального підряду, договору поставки, надання послуг, зовнішньоекономічного договору, порядку визначення та відшкодування збитків у разі неналежного виконання договірних зобов'язань тощо. Обгрунтовано думку про необхідність внесення змін до законодавства в частині надання суб'єктам господарювання можливості договірного обмеження зобов'язань зі сплати фактичних збитків та заподіяної шкоди, можливості вільно використовувати проформи міжнародних профільних організацій у разі, якщо їх положення не суперечать імперативним нормам украӥнського законодавства та загальним принципам господарювання, визначеним у статті 6 Господарського кодексу Украӥни.

Ключові слова: EPC-контракт, FIDIC, господарський договір, змішаний договір, непойменований договір, іноземний елемент.

Постановка проблеми. Нині Україна переходить до чергового етапу розвитку правовідносин у сфері капітального будівництва та енергетики. Це пов'язано зі реалізацією проєктів електростанцій, що використовують відновлювальні джерела енергії (далі - ВДЕ). За даними Національної комісії, що здійснює державне регулювання у сферах енергетики та комунальних послуг, лише в третьому кварталі 2019 року було введено в експлуатацію 956 МВт «зелених» потужностей, що майже у 6 разів більше, ніж за аналогічний період 2018 року, а 97,8\% з цих потужностей складають вітряні і сонячні електростанції [1].
Разом зі стрімким розвитком галузі почали з'являтись досі майже відсутні в Україні договірні відносини. Зокрема, широкої популярності набуло укладення так званих ЕРС-контрактів (від англ. "Engineering, Procurement and Construction”) 3 метою будівництва станцій «під ключ».

Метою статті $€$ дослідження генези поняття «ЕРС-контракт», визначення його ключових особливостей як змішаного договору на основі типових форм, розроблених Міжнародною Федерацією інженерів-консультантів (далі - FIDIC). 
Також слід зауважити, що впровадження стандартів FIDIC в Україні набуває поширення не лише у сфері ВДЕ, але й під час реалізації інфраструктурних проєктів. Зокрема, інженер-консультант FIDIC здійснює контроль за виконанням капітального ремонту доріг підрядниками Державного агентства автомобільних доріг України [2], а Адміністрація морських портів України в оновленій документації на поглиблення дна в морському порті «Південний» відобразила умови типових контрактів FIDIC з урахуванням вимог українського законодавства [3]

Слід відразу ж наголосити, що досі жоден 3 вітчизняних вчених-юристів не займався дослідженням походження чи правової природи ЕРС-контрактів, адже більше уваги нині приділяється договору генерального підряду (Г.М. Гриценко, М.С. Біленко, А.В. Гаврилов, I.I. Банасевич), інжинірингу (К.Е. Насурлаєва, I.О. Кириченко) та договору про надання послуг (В.С. Мілаш, Д.Ю. Сурай), на відміну від юристів-практиків, для яких проблема укладення та виконання ЕРС-контрактів наразі досить актуальна.

Виклад основного матеріалу. У національному законодавстві України поняття «контракт» ототожнюють 3 зовнішньоекономічним договором. Про це свідчать положення статей 382-383 ГК України та статті 1 Закону України «Про зовнішньоекономічну діяльність», яка визначає, що зовнішньоекономічний договір (контракт) - це матеріально оформлена угода двох або більше суб'єктів зовнішньоекономічної діяльності та їх іноземних контрагентів, спрямована на встановлення, зміну або припинення їх взаємних прав та обов'язків у зовнішньоекономічній діяльності [4].

В.Б. Саксонов розглядає зовнішньоекономічний договір (контракт) як різновид господарського договору, що $є$ різновидом цивільно-правового договору, якому притаманні особливості як господарських, так і цивільно-правових договорів [5]. Подібний підхід вважаємо вдалим, адже він дозволяє вийти за рамки тлумачення законодавчих норм і на універсальному рівні використовувати поняття «контракт» відносно складних, комплексних і змішаних договорів, якими $\epsilon$ EPC-контракти. Посилання на загальну теорію права дає можливість зрозуміти, що він укладається виключно письмово.

Як слушно зазначає I.B. Сухоставець, правова природа ЕРС-контрактів (за проформами FIDIC) є досить дискусійною. Окремі дослідники вважають, що подібні контракти належать до так званого soft law - м'якого права, неправового м'якого права, інші вчені відносять вказані проформи до lex constructionis - системи недержавного регулювання міжнародного будівельного підряду, що відображає звичаї і кілька типових умов міжнародних будівельних контрактів. На основі lex constructionis FIDIC розробляе рекомендації у вигляді проформ, типових контрактів, типових регламентів, правових настанов, які використовують замовники і підрядники при укладенні договорів з реалізації проєктів капітального будівництва [6].

Подібна практика укладення договорів за проформами міжнародних асоціацій не $€$ поодинокою, прикладом цього можуть слугувати типові контракти у сфері аграрного сектору, розроблені такими організаціями, як ФОСФА (FOSFA - The Federation of Oils, Seeds and Fats Associations - Федерація асоціацій торгівлі оліями, олійними продуктами і жирами) та ГАФТА (GAFTA - The Grain and Feed Trade Association - Міжнародна асоціація торгівлі зерном та кормами) [7]

Протягом багатьох років FIDIC займається діяльністю з розробки типових проформ контрактів у сфері цивільного будівництва. У 1957 році FIDIC опублікувала свій перший контракт з назвою «Форма договору на виконання робіт з цивільного будівництва» (з англ. "The Form of contract for works of Civil Engineering construction"). Як випливає з назви, ця перша проформа мала на меті урегулювати підрядні відносини у сфері цивільного будівництва і згодом отримала назву «Червона книга» (з англ. "The Red Book") у зв'язку з кольором іï обкладинки. Всі наступні проформи були вже традиційно названі за подібним принципом («Срібна книга», «Жовта книга» тощо).

Перша проформа FIDIC була розроблена спільно з Міжнародною федерацією 3 будівництва і цивільних робіт (з англ. "International federation of Building and Public works"). Завдяки злагодженим зусиллям FIDIC щодо забезпечення консультацій і прийняття нових форм контрактів вони були визнані Міжнародною федерацією підрядників, Азіатською та Західнотихоокеанською асоціацією підрядників, Асоціацією генеральних підрядників Америки та іншими. У зв'язку з широкою підтримкою 3 боку міжнародних організацій та банків типові контракти FIDIC користуються високою популярністю під час здійсненя будівництва за рахунок коштів міжнародних фінансових установ та організацій [8].

Опублікований в 1999 році документ «Срібна книга» був орієнтований на реалізацію проєктів «під ключ». Цей документ передбачає покладення на підрядника низки ризиків не лише щодо всеохопного про- 
цесу будівництва об'єкта, але й щодо проєктування та пусконалагоджувальних робіт, також він дав поштовх до активного використання і впровадження передбаченої ним концепції ЕРС.

Зважаючи на положення Цивільного кодексу України (далі - ЦК України), Господарського кодексу України (далі - ГК України), Закону України «Про міжнародне приватне право» та низки інших нормативно-правових актів, вважаємо, що ЕРСконтракти в Україні укладати можливо, однак слід пам'ятати про те, що Цивільний кодекс України передбачає велику кількість договірних конструкцій раніше не відомих цивільному законодавству. Це значно полегшує та оптимізує діяльність суб'єктів господарювання, оскільки відсутність законодавчого набору договорів призвела б до зволікання (затягування) в оформленні договірних відносин. Але водночас закріплення правового регулювання тих чи інших договорів у законодавстві зовсім не означає, що сторони повинні конструювати свої зобов'язальні взаємозв'язки у такий спосіб, щоб вони відповідали одній з відомих законодавству договірних моделей [9].

Свобода договору передбачає право вибору виду договору, зокрема і укладення змішаного договору. Згідно $з$ частиною 2 статті 628 ЦК України сторони мають право укласти договір, у якому містяться елементи різних договорів (змішаний договір). До відносин сторін у змішаному договорі застосовуються у відповідних частинах положення актів цивільного законодавства про договори, елементи яких містяться у змішаному договорі, якщо інше не встановлено договором або не випливає із суті змішаного договору [10].

Таким чином, зважаючи на вищевказану норму ЦК України, ЕРС-контракт можна віднести до змішаного договору, адже він поєднує в собі окремі елементи договору будівельного підряду, надання послуг, поставки та інжинірингу (навіть кредитного договору).

Перш ніж з'ясувати те, які елементи договору будівельного підряду притаманні ЕРС-контракту, слід наголосити на тому, що існує певна неузгодженість норм ЦК України та ГК України з приводу прав і обов’язків сторін договору підряду на капітальне будівництво і щодо предмету даного договору.

Так, аналізуючи частину 1 статті 318 ГК України, відразу ж натрапляємо на перший обов'язок підрядника - здійснити будівництво об'єкта своїми силами та засобами [11], натомість частина 1 статті 875 ЦК України такого обов'язку на підрядника не покладає. 3 огляду на це слід зазначити, що ЕРС-контракт передбачає виконання всього фронту робіт підрядником саме за рахунок його власних сил та засобів, безумовно, включаючи можливість виконання робіт субпідрядниками. При цьому за роботу субпідрядників перед замовником відповідає підрядник, тому у разі неякісно виконаних робіт всі претензії щодо недоліків адресуються останньому.

Як слушно зазначає Н.О. Кучаковська, частина 1 статті 318 ГК України покладає на замовника обов'язок передати підряднику проєктно-кошторисну документацію, однак положення частини 1 статті 875 ЦК та пункту 31 Загальних умов укладення та виконання договорів підряду в капітальному будівництві [12] вказують не на імперативність, а на презумпцію такого обов'язку замовника [13].

Тут відразу ж слід зазначити, що стосовно ЕРС-контракту існує певна особливість щодо розробки та затвердження проєктно-кошторисної документації. Зокрема, кошторис проєкту будівництва може бути розроблений підрядником його силами і за його рахунок, але при цьому затверджений замовником (згідно 3 документом «Срібна книга»). Разом з тим не заборонено і покладати на замовника обов'язок передати підряднику вже розроблену і затверджену проєктно-кошторисну документацію (згідно 3 документом «Жовта книга»). Також вимоги до складу і змісту проєктної документації, що передбачені умовами контрактів FIDIC, можуть мати низку відмінностей порівняно 3 нормами чинного законодавства [6].

Що стосується елементів договору поставки, то тут ЕРС-контракт включає в себе всі ті риси, які передбачають положення глави 30 ГК України та статті 264 ГК України. Щоправда, деякі норми українського законодавства, які дістались у спадок від часів Радянського Союзу, все ж таки не можуть бути застосовані. Ідеться про Інструкцію про порядок приймання продукції виробничо-технічного призначення та товарів народного споживання за якістю, затверджену Постановою Ради Міністрів РСР від 25.04.1966 р. № П-7, та Інструкцію про порядок приймання продукції виробничо-технічного призначення і товарів народного споживання за кількістю, затверджену Постановою Ради Міністрів РСР від 14.06.1965 р. № П-6 [14].

Оскільки договір інжинірингу є непойменованим, то спеціальних законодавчих вимог щодо його змісту в Україні немає. Щоправда, підпункт 14.1.85 пункту 14.1 статті 14 Податкового кодексу України містить досить 
широке визначення поняття «інжиніринг», під яким розуміється надання послуг (виконання робіт) із складення технічних завдань, проєктних пропозицій, проведення наукових досліджень і техніко-економічних обстежень, виконання інженерно-розвідувальних робіт з будівництва об'єктів, розроблення технічної документації, проєктування та конструкторського опрацювання об'єктів техніки і технології, надання консультації та авторського нагляду під час монтажних та пусконалагоджувальних робіт, а також надання консультацій, пов'язаних із такими послугами (роботами). Вказане поняття не суперечить правовій природі ЕРС-контракту, адже останній може передбачати здійснення підрядником робіт з інжинірингу певних технічних виробів (наприклад, вітроелектроустановок, атомних реакторів чи інверторів), які згодом стануть частиною комплексного об’єкта. У контексті цього вбачається хибною позиція деяких дослідників, які розглядають договір інжинірингу виключно як невід’ємну частину здійснення будівельних робіт і ототожнюють інжиніринг з авторським наглядом [15]

Водночас низка положень типових проформ суперечить нормам українського законодавства, що викликає необхідність в їх адаптації. Процес адаптації повинен відбуватись виключно 3 умовою отримання ліцензії від FIDIC на внесення змін до типової форми контракту з огляду на авторські права розробників на його текст. Наприклад, положення, які стосуються вирішення спорів радою з врегулювання суперечок, як правило, видаляються з контрактів. На жаль, вказане положення рідко використовується в Україні [6].

Під час адаптації Загальних умов контрактів FIDIC окремої уваги заслуговує те, що розробники керувались принципами англійського права, тому левова частка термінології, яка вживається в документі «Срібна книга», не має аналогів в українському законодавстві. Прикладами можуть слугувати поняття «заздалегідь оцінені збитки» (з англ. "liquidated damages"), «обмеження відповідальності» (з англ. "limitation of liability"), у зв'язку з чим виникає необхідність у застосуванні до умов договору норм англійського, а не українського законодавства. Ця проблема вирішується за допомогою включення до складу договірних сторін так званого іноземного елементу, передбаченого Законом України «Про міжнародне приватне право», стаття 5 якого передбачає наявність автономії волі у сторін правочину, що надає їм змогу вибору права, яке буде застосовуватись сторони правочину.
Також частина 4 статті 5 вищеназваного Закону України містить вказівку на те, що вибір права щодо окремих частин правочину повинен бути явно вираженим. Водночас зрозуміло, що відносини щодо виробництва і поставки товарів або обладнання згідно з ЕРС-контрактом можуть бути врегульовані нормами права іншої держави як «офшорна» частина договору, але щодо капітального будівництва сторони повинні передбачити застосування імперативних норм національного законодавства, адже воно буде здійснюватися безпосередньо на території України («оншорна» частина договору).

Саме необхідність наявності іноземного елементу для можливості врегулювання відносин сторін не за нормами українського законодавства робить ЕРС-контракт особливим видом змішаного договору.

Вважаємо за необхідне надати визначення поняттю «ЕРС-контракт». Отже, ЕРС-контракт - це особливий вид змішаного договору, укладений відповідно до типових форм, затверджених міжнародними профільними організаціями, згідно з яким підрядник відповідає за проєктування, поставку, будівництво, пусконалагоджувальні роботи та введення об́'єкта в промислову експлуатацію у визначені строки, а в замовник зобов'язаний передати в належному стані будівельний майданчик підряднику та оплатити роботи відповідно до затвердженого графіку платежів, і який, як правило, містить ознаки зовнішньоекономічного договору.

\section{Висновки}

Сторони, не маючи можливості врегулювати відносини поіменованим договором, вимушені укладати непоіменований змішаний договір із застосуванням матеріального права інших держав (Англії, Німеччини тощо) і саме таким чином проводити договірні транзакції в закордонних юрисдикціях. Дане питання потребує правового врегулювання.

3 огляду на викладене пропонуємо доповнити:

1) статтю 225 ГК України частиною 5 такого змісту: «Суб'єкти господарювання мають право самостійно визначати склад та максимальний розмір відшкодування збитків, спричинених невиконанням договірних зобов'язань»;

2) статтю 179 ГК України частиною 8 в такій редакції: «При укладенні господарських договорів сторони можуть використовувати проформи міжнародних профільних організацій, якщо їх положення не суперечать імперативним нормам законодавства та загальним принципам господарювання, визначеним у статті 6 цього Кодексу». 


\section{Список використаних джерел:}

1. НКРЕКП інформує про розвиток сектору ВДЕ у III кварталі 2019 року. НКРЕКП сайт Національної комісії, що здійснює державне регулювання у сферах енергетики та комунальних послуг. URL: https://www.nerc.gov.ua/ ?news=9438 (дата звернення: 04.12.2019).

2. Новак С.: «Починаємо капітальний ремонт м-01. Технічний контроль за будівельними роботами на об’єкті здійснює інженер-консультант FIDIC» : сайт Державного агентства автомобільних доріг України / ДААД України. URL https://ukravtodor.gov.ua/press/news/slavomir novak pochynaiemo kapitalnyi remont m-01 tekhnichnyi_kontrol_za_budivelnymy_robotamy_na_ob_yekti_zdiisniuie_inzhener-konsultant_fidic. html (дата звернення: 04.12.2019).

3. АМПУ спростить контрактну документацію за міжнародними стандартами FIDIC : сайт Адміністрації морських портів України / АMП України. URL: http://uspa.gov.ua/ru/ pres-tsentr/novini/novini-ampu/15250-ampu-uprostitkontraktnuyu-dokumentatsiyu-po-mezhdunarodnymstandartam-fidic (дата звернення: 04.12.2019).

4. Про зовнішньоекономічну діяльність:Закон Українивід 16.04.1991№959-XII.URL https://zakon.rada.gov.ua/laws/show/959-12 (дата звернення: 04.12.2019).

5. Саксонов В.Б. Правові особливості зовнішньоекономічних договорів (контрактів) України. Науковий вісник Дніпропетровського державного університету внутрішніх справ. 2012. № 2. C. 252-260.

6. Сухоставец И. Контракты FIDIC. Практическоеприменение в Украине. ЮРЛІГА: сайт. URL https://jurliga.ligazakon.net/analitycs/186294 kontrakty-fidic-prakticheskoe-primenenie-v-ukraine (дата звернення: 04.12.2019).

7. Гиренко І., Пинчук Д. Недержавне регулювання зовнішньоекономічних договорів проформами міжнародних асоціацій. Internauka. Series "Juridical Sciences" : International scientific journal. URL: https://www.inter-nauka.com/uploads/ public/15420364133335.pdf (дата звернення: 04.12.2019).
8. Koko Udom. A brief introduction to FIDIC contracts // National Building Specification / NBS URL: https://www.thenbs.com/knowledge/a-briefintroduction-to-fidic-contracts (дата звернення: 04.12.2019)

9. Тупицька $Є$. Щодо питання поіменованості чи непоіменованості договору новації боргу у позикове зобов'язання. Форум права. 2009. № 3. URL: http://nbuv.gov.ua/UJRN/FP_index. htm 2009397 (дата звернення: 04.12.2019).

10. Цивільний кодекс України : Закон України від 16.01.2003 р. № 435-IV. URL: https:// zakon.rada.gov.ua/laws/show/435-15 (дата звернення: 04.12.2019).

11. Господарський кодекс України : Закон України від 16.01.2003 р. № 436-IV. URL: https://zakon.rada.gov.ua/laws/main/436-15 (дата звернення: 04.12.2019).

12. Загальні умови укладення та виконання договорів підряду в капітальному будівництві : Постанова КМ України від 01.08.2005 р. № 669. URL: https:// zakon.rada.gov.ua/laws/show/668-2005-\%D0\%BF (дата звернення: 04.12.2019).

13. Кучаковська Н. Правове регулювання договору підряду на капітальне будівництво: окремі аспекти. Підприємниитво, господарство $i$ право. 2017. № 5. URL: http:// nbuv.gov.ua/UJRN/Pgip_2017_5_14 (дата 3вернення: 04.12.2019).

14. Третяк В. Проблеми правового регулювання поставки товару в українському законодавстві. Репозитарій Національного Авіаційного Університету / HAУ. URL: http:// er.nau.edu.ua/bitstream/NAU/35657/1/\%D0 \% A2\% D 1\%80\%D0\%B5\% D1\%82\%D1\%8F\%D0 $\%$ BA\%20\%D0\%92.\%D0\%AE..pdf (дата звернення: 04.12.2019).

15. Кириченко I. До питання визначення правової природи договору інжинірингу. URL: http://www.visnyk-juris.uzhnu.uz.ua/file/No.46/ part_1/23.pdf (дата звернення: 04.12.2019).

16. Галунько $\quad$ В.В. Науково-практичний коментар до Господарського кодексу України. Київ : Професіонал, 2019. С. 528.

Due to the rapid development of social relations in Ukraine, national legislation can t keep up to regulate them properly, which force businesses to use the rules of foreign jurisdictions or the pro-forms of international specialized organizations to carry out the contractual transactions more frequently. The article provides examples of how the complex contractual relations are governed in practice, why Ukrainian legislation requires changes, and how the businesses are forced to protect its interests while entering into turnkey contracts.

This article is concerning the genesis of the term "EPC-contract" and its legal nature. The author has researched the emergence of the contract templates, which were created by International Federation of Consulting Engineers, in particular Silver book which envisages realization of the construction projects in the turn-key way and opportunity to use such templates by the entities in Ukraine. This research also includes general analysis of the EPC-contract through the prism of the Ukrainian legislation, which indicates the features and problems with its conclusion and implementation. In addition, author definition concept of "EPC-contract" was suggested in connection with the fact that according to the Ukrainian legislation such an agreement is defines as unnamed and mixed with a specific features.

Also, article analyzes the use of certain provisions of the economic and civil law which are reflected in EPC contracts, in particular: the features of approval of the building design documentation, the conclusion 
of the turnkey contract, the supply contract, the provision of services, foreign trade agreement, the procedure for determining and compensation for losses in case of improper performance of contractual obligations, etc. It is substantiated the opinion of amending the legislation regarding the provision of the contractual limitation of obligations for the actual losses fees of and damages caused to economic entities as well as the possibility to freely use the international organizations pro-form in case when its provisions do not contradict the imperative norms of the Ukrainian legislation and the principles of economic management as defined in Article 6 of the Economic Code of Ukraine.

Key words: EPC-contract, FIDIC, economic contract, mixed contract, unnamed contract, foreign element. 